\title{
Combined Use of Trichoderma atroviride CCTCCSBW0199 and Brassinolide to Control Botrytis cinerea Infection in Tomato
}

\author{
Ting-ting Li, ${ }^{1}$ Jing-di Zhang, ${ }^{1}$ Jia-quan Tang, ${ }^{1}$ Zhi-cheng Liu, ${ }^{1}$ Ya-qian Li, ${ }^{1}$ and Jie Chen, ${ }^{1 \dagger}$ and Li-wen Zou ${ }^{2}$ \\ ${ }^{1}$ School of Agriculture and Biology, Shanghai Jiao Tong University/State Key Laboratory of Microbial Metabolism/Key \\ Laboratory of Urban Agriculture (South), Ministry of Agriculture and Rural Affairs, Shanghai 200240, P.R. China \\ ${ }^{2}$ Dalian Wafangdian Agricultural Technology Extension Service Center, Dalian 116300, P.R. China
}

\begin{abstract}
Tomato gray mold caused by Botrytis cinerea is one of the main diseases of tomato and significantly impacts the yield and quality of tomato fruit. The overuse of chemical fungicides has resulted in the development of fungicide-resistant strains. Biological control is becoming an alternative method for the control of plant diseases to replace or decrease the application of traditional synthetic chemical fungicides and genus Trichoderma is widely used as a biological agent for controlling tomato gray mold. Brassinolide (BR) is a plant-growth-promoting steroid. To enhance the efficiency and stability of Trichoderma activity against $B$. cinerea, an optimal combination of Trichoderma atroviride CCTCCSBW0199 and BR that controls

of $B$. cinerea. BR reduced growth of $B$. cinerea and had no effect on the sporulation and growth of Trichoderma spp. An application of metabolites of a Trichoderma sp. + BR reduced gray mold on tomato leaves by approximately $70.0 \%$. Furthermore, the activities of induced defense responserelated enzyme, such as peroxidase, superoxide dismutase, catalase, and phenylalanine ammonia-lyase were increased in tomato plants treated with a Trichoderma sp. + BR. Our data suggested that applying a mix of metabolites of T. atroviride CCTCCSBW0199 + BR was effective at reducing gray mold of tomato and may lay a theoretical foundation for the development of novel biofungicides.
\end{abstract} B. cinerea infection in tomato was identified. Strain CCTCCSBW0199 was found to have antagonistic activity against $B$. cinerea both in vitro and in vivo. In addition, a fermented culture of chlamydospores and metabolites, or metabolites only of strain CCTCCSBW0199 also reduced growth
Keywords: Botrytis cinerea, brassinolide, cultural and biological practices, disease management, fungi, tomato gray mold, Trichoderma atroviride, vegetables
Tomato gray mold is a fungal disease caused by Botrytis cinerea that occurs worldwide, especially when the environmental temperature is at least $20^{\circ} \mathrm{C}$ and the humidity is high (Hannusch and Boland 1996; Ning 2013). Tomato gray mold results in defoliation and flower and fruit abortion, consequently affecting the yield and quality of tomato fruit (Wang et al. 2018). On average, tomato gray mold causes 20.0 to $30.0 \%$ yield loss, with up to $50.0 \%$ loss in the case of severe outbreaks (Zhao et al. 2014). Tomato gray mold is traditionally managed using chemical fungicides (Wang et al. 2018); however, long-term use of chemical fungicides leads to a high risk of the pathogen developing resistance, which seriously challenges sustainable control of the disease (Elad and Shtienberg 1995). Procymidone and carbendazim, for instance, are now rarely used to control the disease because $B$. cinerea has already developed strong resistance to these fungicides (Sun et al. 2010). Indeed, in some areas of China, the resistance rate of $B$. cinerea to these two fungicides is $100.0 \%$ (Liu et al. 2016). Therefore, the use of biological control to inhibit tomato gray mold has attracted much attention.

${ }^{\dagger}$ Corresponding author: J. Chen; jiechen59@sjtu.edu.cn

T.-t. Li and J.-d. Zhang share joint first authorship.

Funding: This work was supported by the National Key Research and Development Program of China (2017YFD0200403), the Key International Intergovernmental Scientific and Technological Innovation Cooperation Project (2017YFE0104900), the National Natural Science Foundation of China (31672072, 31872015, and 31750110455), the Earmarked Fund for the China Agriculture Research System (CARS-02), the Key Project of the Shanghai Committee of Science and Technology (18391902400), the Shanghai Agriculture Extension Project (No1-6,2017), and the Agriculture Research System of Shanghai, China (201710).

The author(s) declare no conflict of interest.

Accepted for publication 13 January 2020.

() 2020 The American Phytopathological Society
Trichoderma spp. are widely used as biological control agents against plant diseases with minimal environmental risks. Trichoderma atroviride has been successfully used to control cucumber and tomato gray mold (Lei 1998). Trichoderma spp. protect host plants from infection by various pathogens via mechanisms that include nutritional competition, mycoparasitism, antibiotic activity, and induced resistance (Harman 2006). In addition, treatment of tomato with Trichoderma spp. results in altered expression of defense-related genes such as those involved in the jasmonic acid (Harel et al. 2014), salicylic acid, and abscisic acid pathways (Fernández et al. 2014). However, compared with soil applications, foliar applications of Trichoderma spp. are usually less effective at reducing disease; therefore, the combined use of Trichoderma spp. and other environmentally friendly biochemicals is proposed to be a good alternative for improving foliar applications of Trichoderma spp. for biocontrol (Harel et al. 2014).

Brassinolide (BR), a plant hormone that belongs to the brassinosteroid group, is involved in many cellular processes, including cell expansion and division, tissue differentiation, flowering, senescence, and abiotic stress responses (Xia et al. 2011). BR may also play an organ-specific role in tomato fruit development (Nomura et al. 2005). BR reportedly enhances plant resistance by improving plant osmotic regulation and increasing the activity of various protective enzymes such as peroxidase (POD) and superoxide dismutase (SOD) (Damghan 2009). Brassinosteroid hormones are important signaling molecules that stimulate the plant immune response (Yuan et al. 2018) and enhance plant growth and resistance to stress (Clouse and Sasse 1998; Mandava 1988; Vardhini et al. 2008). For example, upregulation of brassinosteroid cascade signaling is closely associated with disease resistance in barley (Ali et al. 2014) and plant growth and stress resistance in tomato (Vardhini et al. 2008).

There are few reports to date of combinations of BR and biological agents to manage disease. When BR was combined with a neem oil nuclear extract or Chinese herbal medicinal compounds, the treated plants were found to be more vigorous (i.e., taller) and their stem diameter, shoot fresh weight, and shoot dry weight were all greater. Such growth promotion in plants treated with combinations of biological compounds and BR has been suggested to be the result of increased levels of photosynthetic pigments (Wang et al. 2017). 
Moreover, treatment of maize roots with $T$. harzianum significantly induced maize resistance to Curvularia leaf spot disease by upregulating BR signaling-related genes such as $B A K 1, B R I 1$, and $M Y C$ (Yu et al. 2016). However, to our knowledge, there has been no research on Trichoderma spp. + BR to control plant diseases. We postulated that a Trichoderma sp. + BR would synergistically control tomato gray mold. In this study, we evaluated the effect of a Trichoderma sp. + BR on the severity and incidence of gray mold caused by B. cinerea in tomato.

\section{Materials and Methods}

Materials. Twelve Trichoderma strains (JH3403, GDFS1009, ZJSX5003, H6, D9, CCTCCSBW0199, 1, HN524001, HNZJ4010, HBJZ4007, HNCS3013, and CDCG3007) were provided by the Laboratory of Plant Pathology, Shanghai Jiao Tong University. $B$. cinerea was provided by the Chinese Academy of Agricultural Sciences (J. Zhang et al. 2017). BR powder was provided by Shanghai Lvze Bioengineering Co., Ltd. Seed of the tomato variety Zhongshu No. 4 were purchased from commercial seed shops.

Trichoderma cultivation, and preparation of conidial suspensions and fermented cultures. Trichoderma strains were grown on potato dextrose agar (PDA) plates at $28^{\circ} \mathrm{C}$ for 7 days (Te'o et al. 2002) under a cycle of $14 \mathrm{~h}$ of light and $10 \mathrm{~h}$ of darkness (Li et al. 2015; Masih and Paul 2002). Conidial suspensions were obtained by harvesting spores from the PDA plates using $2 \mathrm{ml}$ of sterile water, then adjusted to the required concentrations. Fermented cultures (FCs) were obtained by inoculating Trichoderma conidial suspensions into potato dextrose broth (PDB) (200 ml per 500-ml Erlenmeyer flask), followed by incubation at $28^{\circ} \mathrm{C}$ and $180 \mathrm{rpm}$ for 5 days in a shaking incubator (Ho et al. 2003). FCs contained hyphae, chlamydospores, and metabolites. FCs containing chlamydospores and metabolites (FCCM) without hyphae were obtained by filtering through four layers of sterile gauze (Giese et al. 2006). FCs containing metabolites (FCM) without hyphae and chlamydospores were obtained by filtering through a $0.22-\mu \mathrm{m}$ Millex-GP Syringe Filter Unit (Millipore Sigma, Burlington, MA, U.S.A.) (Yau et al. 2011).

B. cinerea cultivation, and preparation of conidial suspensions. B. cinerea was grown on PDA at $25^{\circ} \mathrm{C}$ for 7 days (Te'o et al. 2002) under a cycle of $14 \mathrm{~h}$ of light and $10 \mathrm{~h}$ of darkness (Li et al. 2015; Masih and Paul 2002). Conidial suspensions were obtained by washing the spores from PDA plates using $2 \mathrm{ml}$ of sterile water.

Preparation of BR solution. The BR stock solution used was prepared from $99.9 \%$ BR powder, diluted with $95.0 \%$ alcohol to a concentration of $1 \mathrm{mg} / \mathrm{ml}$ (Kamuro and Inada 1991). From the stock solution $(1 \mathrm{mg} / \mathrm{ml})$, BR solutions of $1,0.2$, and $0.1 \mu \mathrm{g} / \mathrm{ml}$ were prepared by diluting with sterile water.

Screening of antagonistic Trichoderma strains against $B$. cinerea. One mycelial disc (4 $\mathrm{mm}$ in diameter) each of a Trichoderma sp. and B. cinerea was excised from the growing edges of 7-day-old cultures and placed $2 \mathrm{~cm}$ apart on opposite sides of PDA plates $(90 \mathrm{~mm})$. The plates were incubated for 5 to 6 days at 20 and $28^{\circ} \mathrm{C}$. A control of $B$. cinerea grown alone on PDA plates was used. The growth rate of $B$. cinerea was determined by measuring the colony diameter. The percent inhibition was calculated as follows: percent inhibition $(\%)=[$ pathogen colony diameter in the control treatment pathogen colony diameter in the challenge treatment)/pathogen colony diameter in the control treatment] $\times 100$. (Cheng et al. 2012).

PDA plates amended with $10.0 \%$ T. atroviride CCTCCSBW0199 FCM were prepared and a disc of $B$. cinerea culture (4 $\mathrm{mm}$ in diameter) was placed in the center of the PDA medium and incubated at $25^{\circ} \mathrm{C}$ (optimum growth temperature for $B$. cinerea) for 5 to 7 days. Nonamended PDA served as the control. The colony diameter of B. cinerea was measured to identify the inhibitory effects of Trichoderma FCM on the pathogen.

Effects of BR on $B$. cinerea growth in vitro. PDA plates amended with BR solution at $0.2 \mu \mathrm{g} / \mathrm{ml}$ were prepared and inoculated with a disc of $B$. cinerea culture placed in the center of the plates. Nonamended PDA served as the control. All plates were incubated at $25^{\circ} \mathrm{C}$ for 5 days. The colony diameter of the pathogen was measured to identify the effects of BR on B. cinerea growth.
To observe the effect of BR on the hyphal morphology of B. cinerea, PDB was amended with BR at $0.2 \mu \mathrm{g} / \mathrm{ml}$ (or not amended for the control). The broth was inoculated with a spore suspension of $B$. cinerea $\left(1 \times 10^{6}\right.$ spores $\left./ \mathrm{ml}\right)$, then incubated at $25^{\circ} \mathrm{C}$ in an incubator with shaking at $180 \mathrm{rpm}$ for 3 days. The hyphae of the pathogen were harvested from the broth using a pipette and rinsed with doubledistilled water $\left(\mathrm{ddH}_{2} \mathrm{O}\right)$. A small sample of hyphae was fixed in $2.5 \%$ glutaraldehyde $(0.1 \mathrm{M})$ under a vacuum at $4^{\circ} \mathrm{C}$ for $24 \mathrm{~h}$. The sample was dehydrated according to a described method (Wright 2000) and placed in acetone/epoxy resin (1:1) for $1 \mathrm{~h}$ followed by overnight incubation in acetone/epoxy resin (1:2). Subsequently, the sample was placed in pure epoxy resin for $8 \mathrm{~h}$ and then in a $60^{\circ} \mathrm{C}$ oven for $48 \mathrm{~h}$ of polymerization. Ultrathin slices ( $50 \mathrm{~nm}$ thick) of the sample were prepared using a Lycra ultrathin microtome. The sections were stained with uranium acetate for $5 \mathrm{~min}$, washed with $\mathrm{ddH}_{2} \mathrm{O}$ several times, then stained with lead citrate for $6 \mathrm{~min}$. Finally the samples were washed in $\mathrm{ddH}_{2} \mathrm{O}$ for 2 min, dried, and observed under a transmission electron microscope (120 kV Biology Transmission Electron Microscope; Tecnai G2 SpiritBiotwin) (Buckley et al. 1966).

Effects of BR on T. atroviride CCTCCSBW0199. To evaluate the effect of BR on mycelial growth of T. atroviride CCTCCSBW0199, PDA plates were amended with BR at $1,0.2$, and $0.1 \mu \mathrm{g} / \mathrm{ml}$. PDA alone served as the control. Discs (4 $\mathrm{mm}$ in diameter) of a Trichoderma sp. excised from the growing edge of a 7-day-old culture were placed in the center of the PDA plates. All plates were incubated at $28^{\circ} \mathrm{C}$ (optimum growth temperature for $T$. atroviride) for 5 days. The diameter of Trichoderma colonies was measured to identify the effects of BR on the growth of T. atroviride CCTCCSBW0199.

To evaluate the effect of $\mathrm{BR}$ on the sporulation of $T$. atroviride CCTCCSBW0199, PDB (100 ml per 250-ml Erlenmeyer flask) was amended with BR solution at $1,0.2$, or $0.1 \mu \mathrm{g} / \mathrm{ml}$; PDB alone served as the control. The broth was inoculated with a conidial suspension $\left(1.0 \times 10^{6}\right.$ spores $\left./ \mathrm{ml}\right)$ and the flasks were incubated at $28^{\circ} \mathrm{C}$ and $180 \mathrm{rpm}$ for 5 days. Hyphae were removed, and Trichoderma spores were counted using a hemocytometer.

Evaluations of BR contribution to the inhibitory effect of $T$. atroviride CCTCCSBW0199 on the growth of $B$. cinerea. Mycelial discs (4 $\mathrm{mm}$ in diameter) of both Trichoderma spp. and B. cinerea were placed $2 \mathrm{~cm}$ apart on PDA plates amended with different concentrations of BR $(1,0.2$, and $0.1 \mu \mathrm{g} / \mathrm{ml})$. PDA without BR served as the control. B. cinerea grown alone on PDA plates was also prepared. All plates were incubated at $25^{\circ} \mathrm{C}$ for 5 days. The pathogen colony diameter was measured, and the percent inhibition was calculated as follows: percent inhibition $(\%)=[$ (single pathogen colony diameter - pathogen colony diameter in the treatment)/single pathogen colony diameter] $\times 100$.

Greenhouse evaluations of the effect of $T$. atroviride CCTCCSBW0199 and BR on gray mold of tomato. Tomato seed were surface sterilized with $2.0 \%$ sodium hypochlorite for $3 \mathrm{~min}$, rinsed with sterile water, and placed in sterile petri dishes containing moistened filter paper. The seed were allowed to germinate at room temperature for 2 days. The germinated seed were then transplanted into $15-\mathrm{cm}$-diameter pots. The growing media was composed of peat, vermiculite, and perlite at a ratio of 4:1:1. Each treatment included three pots and 5 plants/pot. All of the pots were maintained under a cycle of $14 \mathrm{~h}$ of light $\left(25^{\circ} \mathrm{C}\right)$ and $10 \mathrm{~h}$ of darkness $\left(15^{\circ} \mathrm{C}\right)$ in a greenhouse.

To evaluate the effects of $T$. atroviride CCTCCSBW0199 + BR on tomato gray mold, T. atroviride FCCM of different concentrations were prepared, and BR stock solution at $1 \mathrm{mg} / \mathrm{ml}$ was amended with each T. atroviride FCCM to a final concentration of $0.2 \mu \mathrm{g} / \mathrm{ml}$. Sterile water served as a control. The following treatments were compared: (i) T. atroviride FCCM at $1 \times 10^{6}$ spores $/ \mathrm{ml}$, (ii) T. atroviride FCCM at $1 \times 10^{7}$ spores $/ \mathrm{ml}$, (iii) T. atroviride $\mathrm{FCCM}$ at $1 \times 10^{8}$ spores $/ \mathrm{ml}$, (iv) T. atroviride FCCM at $1 \times 10^{9}$ spores $/ \mathrm{ml}$, (v) T. atroviride FCCM at $1 \times 10^{6}$ spores $/ \mathrm{ml}+\mathrm{BR}$ at $0.2 \mu \mathrm{g} / \mathrm{ml}$, (vi) T. atroviride $\mathrm{FCCM}$ at $1 \times 10^{7}$ spores $/ \mathrm{ml}+\mathrm{BR}$ at $0.2 \mu \mathrm{g} / \mathrm{ml}$, (vii) T. atroviride $\mathrm{FCCM}$ at $1 \times 10^{8}$ spores $/ \mathrm{ml}+\mathrm{BR}$ at $0.2 \mu \mathrm{g} / \mathrm{ml}$, (viii) T. atroviride FCC Maty $1 \times 10^{9}$ spores $/ \mathrm{ml}+\mathrm{BR}$ at $0.2 \mu \mathrm{g} / \mathrm{ml}$, and (ix) control = sterile water.

To evaluate of the optimal T. atroviride CCTCCSBW0199 + BR application sequence, $T$. atroviride FCCM $\left(1 \times 10^{8}\right.$ spores $\left./ \mathrm{ml}\right)$ and 
$\mathrm{BR}$ at $0.2 \mu \mathrm{g} / \mathrm{ml}$ solution were prepared. The following treatments were compared: (i) $T$. atroviride FCCM at $1 \times 10^{8}$ spores $/ \mathrm{ml}+\mathrm{BR}$ at $0.2 \mu \mathrm{g} / \mathrm{ml}$ (24 h later), (ii) BR at $0.2 \mu \mathrm{g} / \mathrm{ml}+T$. atroviride FCCM at $1 \times 10^{8}$ spores $/ \mathrm{ml}$ (24 h later), (iii) T. atroviride FCCM at $1 \times 10^{8}$ spores $/ \mathrm{ml}+\mathrm{BR}$ at $0.2 \mu \mathrm{g} / \mathrm{ml}$ (at the same time), (iv) T. atroviride FCCM alone at $1 \times 10^{8}$ spores $/ \mathrm{ml},(\mathrm{v}) \mathrm{BR}$ alone at $0.2 \mu \mathrm{g} / \mathrm{ml}$, and (vi) sterile water was sprayed as the control.

The treatment solutions were sprayed onto tomato seedlings at the three- to five-leaf stage using a spray bottle $(10 \mathrm{ml} /$ plant $)$ (Chen et al. 1982; Sauer et al. 1986). After 24 h, a B. cinerea conidial suspension $\left(1.0 \times 10^{6}\right.$ spores $\left./ \mathrm{ml}\right)$ was sprayed onto the leaves, and all plants were humidified to keep soil moisture at 20 to $30 \%$ for 5 days. Gray mold severity was assessed 5 days after inoculation (DAI) using a scale of 0 to 9 , where $0=$ no disease spots, $1=$ the disease spot area accounted for 1.0 to $10.0 \%$ of the leaf area, $3=$ the disease spot area accounted for 11.0 to $25.0 \%$ of the leaf area, $5=$ the disease spot area accounted for 26.0 to $50.0 \%$ of the leaf area, $7=$ the lesion area accounted for 51.0 to $75.0 \%$ of the leaf area, and $9=$ the disease spot area accounted for more than $75.0 \%$ of the leaf area. The disease index and control efficiency of gray mold on the tomato leaves were calculated as follows: disease index $=100 \times[\Sigma$ (number of leaves for each disease severity $\times$ disease rank)] /(total number of leaves $\times 9$ ) and control efficiency $(\%)=[($ disease index of the control - disease index of the treatment)/disease index of the control] $\times 100$.

Determination of defense response-related enzyme activity. Solutions of $T$. atroviride FCCM at $1 \times 10^{8}$ spores $/ \mathrm{ml}$ and BR at $0.2 \mu \mathrm{g} / \mathrm{ml}$ were prepared and sprayed onto the leaves of threeto five-leaf tomato seedlings at the same time using a spray bottle $(10 \mathrm{ml} / \mathrm{plant})$. The following treatments were compared: (i) $T$. atroviride $\mathrm{FCCM}$ at $1 \times 10^{8}$ spores $/ \mathrm{ml}+\mathrm{BR}$ at $0.2 \mu \mathrm{g} / \mathrm{ml}$, (ii) T. atroviride FCCM alone at $1 \times 10^{8}$ spores $/ \mathrm{ml}$, (iii) $\mathrm{BR}$ alone at $0.2 \mu \mathrm{g} / \mathrm{ml}$, and (iv) sterile water was sprayed as the control. After $24 \mathrm{~h}$, a $B$. cinerea conidial suspension $\left(1.0 \times 10^{6}\right.$ spores $\left./ \mathrm{ml}\right)$ was sprayed onto the leaves, and all plants were humidified to keep soil moisture at 20.0 to $30.0 \%$ for 5 days. Plant tissue homogenates were prepared as follows. Tomato leaves and phosphate buffer $(0.1 \mathrm{~mol} / \mathrm{liter}, \mathrm{pH}$ of 7 to 7.4$)$ in a $1: 9(\mathrm{wt} / \mathrm{vol})$ ratio were ground in liquid nitrogen. An aliquot of the plant tissue suspension (0.1 $\mathrm{g} / \mathrm{ml}$ ) was centrifuged at $5,000 \mathrm{rpm}$ for $10 \mathrm{~min}$ at $4^{\circ} \mathrm{C}$, and the supernatant was collected. POD and SOD activity followed protocols recommended by Shanghai Cablebridge Biotechnology Co., Ltd. Catalase (CAT) and phenylalanine ammonia-lyase (PAL) activities were determined according to the protocols recommended by Shanghai Jianglai Biotechnology Co., Ltd. One unit of enzyme activity is defined as the amount of enzyme required to catalyze the conversion of $1 \mu \mathrm{mol}$ of substrate (or the relevant group in a

Table 1. Screening of Trichoderma strains with biocontrol activity against Botrytis cinerea growth

\begin{tabular}{lccccc}
\hline & \multicolumn{2}{c}{$\mathbf{2 0}^{\circ} \mathbf{C}$} & & \multicolumn{2}{c}{$\mathbf{2 8}^{\circ} \mathbf{C}$} \\
\cline { 2 - 3 } \cline { 5 - 6 } & $\begin{array}{c}\text { Pathogen } \\
\text { colony } \\
\text { diameter } \\
(\mathbf{c m})\end{array}$ & $\begin{array}{c}\text { Percent } \\
\text { inhibition } \\
(\boldsymbol{\%})^{\mathbf{z}}\end{array}$ & $\begin{array}{c}\text { Pathogen } \\
\text { colony } \\
\text { diameter } \\
(\mathbf{c m})\end{array}$ & $\begin{array}{c}\text { Percent } \\
\text { inhibition } \\
(\boldsymbol{\%})^{\mathbf{z}}\end{array}$ \\
\hline JH3403 & $3.7 \pm 0.1$ & $59.2 \mathrm{C}$ & & $3.4 \pm 0$ & $62.7 \mathrm{D}$ \\
GDFS1009 & $3.6 \pm 0.1$ & $60.3 \mathrm{CD}$ & & $3.5 \pm 0.1$ & $60.6 \mathrm{C}$ \\
ZJSX5003 & $4.3 \pm 0.1$ & $52.2 \mathrm{~A}$ & & $3.9 \pm 0$ & $57.2 \mathrm{~B}$ \\
H6 & $4.0 \pm 0$ & $55.6 \mathrm{~B}$ & & $4.1 \pm 0.1$ & $54.4 \mathrm{~A}$ \\
D9 & $3.2 \pm 0$ & $64.1 \mathrm{FG}$ & & $3.0 \pm 0.1$ & $66.3 \mathrm{G}$ \\
CCTCCSBW0199 & $2.7 \pm 0.1$ & $69.8 \mathrm{H}$ & & $2.4 \pm 0.1$ & $73.6 \mathrm{H}$ \\
1 & $3.6 \pm 0.1$ & $60.3 \mathrm{CD}$ & & $3.3 \pm 0.1$ & $63.5 \mathrm{DE}$ \\
HN524001 & $3.2 \pm 0$ & $64.4 \mathrm{G}$ & & $3.2 \pm 0$ & $69.6 \mathrm{EF}$ \\
HNZJ4010 & $3.4 \pm 0.1$ & $62.5 \mathrm{E}$ & & $3.0 \pm 0.1$ & $66.7 \mathrm{G}$ \\
HBJZ4007 & $3.3 \pm 0.1$ & $62.9 \mathrm{EF}$ & & $3.0 \pm 0.1$ & $66.7 \mathrm{G}$ \\
HNCS3013 & $3.6 \pm 0.1$ & $60.3 \mathrm{CD}$ & & $3.2 \pm 0.1$ & $64.0 \mathrm{E}$ \\
CDCG3007 & $3.5 \pm 0.1$ & $61.1 \mathrm{D}$ & & $3.1 \pm 0.1$ & $65.5 \mathrm{FG}$ \\
\hline 2Diff & &
\end{tabular}

${ }^{\mathrm{z}}$ Different uppercase letters in the same column indicate significant differences among treatments $(P<0.05)$. substrate) in 1 min under specific conditions, and the activity is expressed as units per milligram of protein (Alici and Arabaci 2016; Jing et al. 2012).

Data analysis. The raw data such as pathogen colony diameters, spore numbers, and incidence numbers from the experiments were organized and saved in Microsoft Excel (version 2013). The pathogen percent inhibition, disease index of tomato leaves, control effects of different treatments, germination rates of Trichoderma spores, and disease incidence rates of tomato leaves were calculated with linear arithmetic functions in Microsoft Excel (version 2013). Analyses of variance (ANOVA) was performed to examine control effects of strain T. atroviride CCTCCSBW0199 at different concentrations, to compare percent inhibitions of $\mathrm{BR}+\mathrm{a}$ Trichoderma sp. at different concentrations, and to test for control effects of $\mathrm{BR}+$ a Trichoderma sp. at various concentrations with the ANOVA least significant difference multiple comparisons command in SPSS (version 18.0). Each experiment was repeated three times, and all treatments were set up in biological triplicate.

\section{Results}

Screening of antagonistic Trichoderma strains against $B$. cinerea. All Trichoderma strains tested inhibited the growth of $B$. cinerea, although inhibitions varied among the strains. Among the tested strains, T. atroviride CCTCCSBW0199 most significantly inhibited the growth of B. cinerea, by 69.8 and $73.6 \%$ at 20 and $28^{\circ} \mathrm{C}$, respectively (Table 1). Similarly, FCM from strain CCTCCSBW0199 inhibited pathogen growth by $73.1 \%$ (Fig. 1). Consequently, all remaining experiments were performed with strain T. atroviride CCTCCSBW0199.

Effects of BR on $B$. cinerea growth in vitro. Vacuole size observed using transmission electron microscopy was larger in $B$. cinerea treated with BR solutions at $0.2 \mu \mathrm{g} / \mathrm{ml}$ compared with the control, indicating that BR interfered with the subcellular structure of the B. cinerea mycelium (Fig. 2).

Effects of BR on T. atroviride CCTCCSBW0199. The mycelial growth of a Trichoderma sp. was not affected by different BR concentrations (Fig. 3). In fact, BR at a concentration of 1 or $0.2 \mu \mathrm{g} / \mathrm{ml}$ stimulated the growth of Trichoderma mycelia compared with the control $(P<0.05)$. However, BR had no effect on sporulation of Trichoderma spp. (Table 2).

Determination of the effect of $\mathrm{BR}$ on $T$. atroviride CCTCCSBW0199-mediated inhibition of $B$. cinerea growth. The inhibitory rates of $T$. atroviride CCTCCSBW0199 + BR solution at $1,0.2$, and $0.1 \mu \mathrm{g} / \mathrm{ml}$ on the growth of $B$. cinerea were $70.3,74.6$, and $69.9 \%$, respectively; higher than the Trichoderma sp. without BR control $(67.0 \%)$. The results showed that BR at 0.2 and $1 \mu \mathrm{g} / \mathrm{ml}$ enhanced the inhibitory effect of $T$. atroviride CCTCCSBW0199 on B. cinerea growth, and that BR solution at $0.2 \mu \mathrm{g} / \mathrm{ml}+$ Trichoderma formulation was the most effective combination against the growth of $B$. cinerea (Table 3 ).

Determination of the effect of $T$. atroviride CCTCCSBW0199 FCCM and BR on tomato gray mold. An application of either $T$.
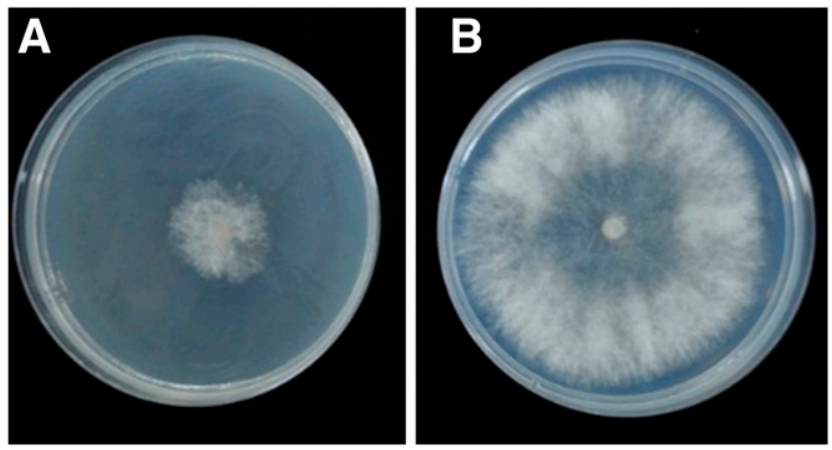

Fig. 1. Inhibitory effects of Trichoderma atroviride CCTCCSBW0199 fermented cultures containing metabolites (FCM) on the growth of Botrytis cinerea. A, Potato dextrose agar (PDA) with FCM and B, control: PDA without FCM. 
atroviride CCTCCSBW0199 FCCM or FCCM + BR significantly reduced the disease index of gray mold on tomato leaves $(P<$ 0.05 ) (Table 4). Percent control of gray mold ranged from 61.1 to $71.3 \%$ for FCCM alone and 62.1 to $74.8 \%$ for FCCM + BR. The lowest concentration of FCCM reduced disease the most. Conversely, a higher concentration of FCCM $\left(1 \times 10^{8}\right.$ spores $\left./ \mathrm{ml}\right)+\mathrm{BR}$ reduced disease the most (Fig. 4; Table 4).

An application of $T$. atroviride FCCM alone at $1 \times 10^{8}$ spores $/ \mathrm{ml}$ followed by an application of BR at $0.2 \mu \mathrm{g} / \mathrm{ml}(24 \mathrm{~h}$ later) and an application of a mix of $T$. atroviride FCCM at $1 \times 10^{8}$ spores $/ \mathrm{ml}+\mathrm{BR}$ at $0.2 \mu \mathrm{g} / \mathrm{ml}$ resulted in similarly high levels of control against the disease (Table 5). Therefore, in enzyme activity experiments, $T$. atroviride FCCM at $1 \times 10^{8}$ spores $/ \mathrm{ml}+\mathrm{BR}$ at $0.2 \mu \mathrm{g} / \mathrm{ml}$ were applied simultaneously for convenience.

Determination of defense-related enzyme activity. POD and CAT activities of the plants peaked 3 DAI. POD and CAT activities in extracts of tomato leaf treated with a Trichoderma sp. + BR reached 5.29 and $15.6 \mathrm{U} / \mathrm{mg}$ of protein, respectively, in contrast to 0.57 and $5.44 \mathrm{U} / \mathrm{mg}$ pf protein, respectively, detected for the control.

Table 2. Effects of brassinolide (BR) on Trichoderma sporulation

\begin{tabular}{lc}
\hline Treatment & Spore concentration $\left(\mathbf{1 0}^{\mathbf{6}} \mathbf{\text { spores}} / \mathbf{m l}\right)^{\mathbf{z}}$ \\
BR at $1 \mu \mathrm{g} / \mathrm{ml}$ & $246.7 \pm 12.3 \mathrm{~A}$ \\
BR at $0.2 \mu \mathrm{g} / \mathrm{ml}$ & $226.7 \pm 11.4 \mathrm{~A}$ \\
BR at $0.1 \mu \mathrm{g} / \mathrm{ml}$ & $224.7 \pm 11.2 \mathrm{~A}$ \\
Control & $235.7 \pm 11.8 \mathrm{~A}$ \\
\hline
\end{tabular}

${ }^{\mathrm{z}}$ Different uppercase letters in the same column indicate significant differences among treatments $(P<0.05)$.

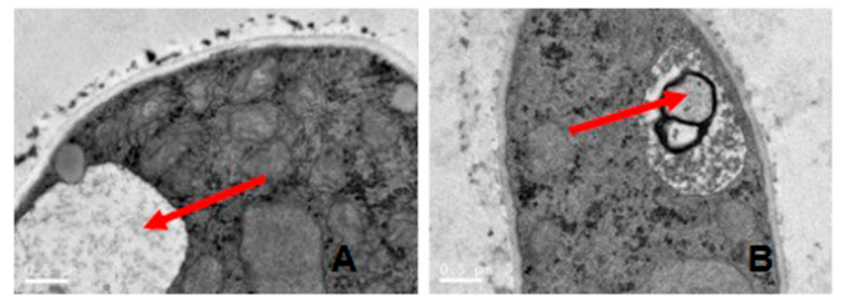

Fig. 2. Effects of brassinolide (BR) on the mycelial ultrastructure of Botrytis cinerea. A, BR at $0.2 \mu \mathrm{g} / \mathrm{ml}$, bar $=1 \mu \mathrm{m}$, and B, control (no BR), bar $=0.5 \mu \mathrm{m}$. Images show changes in size of the vacuole that is indicated by an arrow.

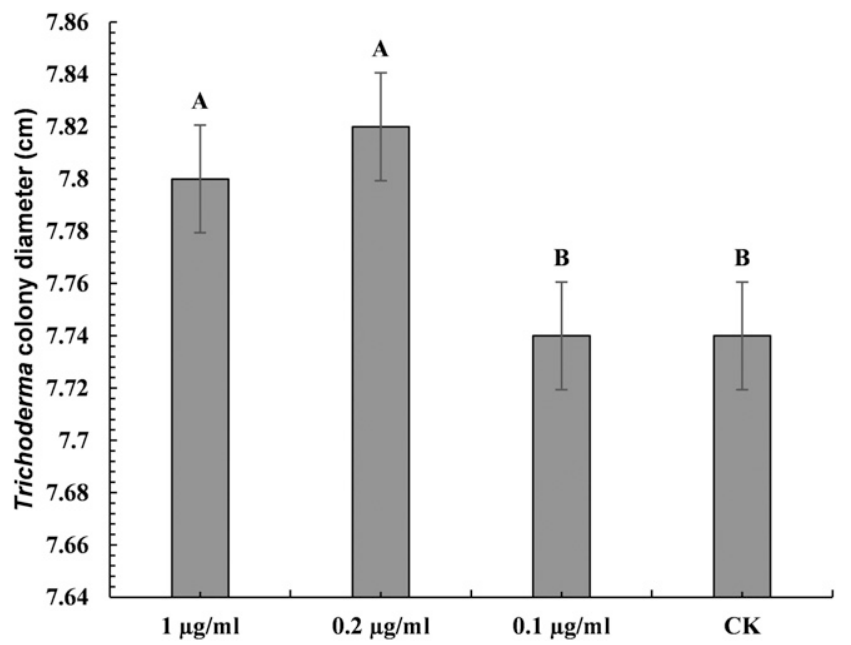

Fig. 3. Effects of applied concentrations of brassinolide (BR) on the growth of Trichoderma atroviride CCTCCSBW0199. CK (control) $=$ no BR. Different uppercase letters indicate significant differences among treatments $(P<0.05)(n=3)$.
Activities in the single treatments were lower than those with a Trichoderma sp. + BR for 3 DAI (Fig. 5A and B).

SOD activity peaked at $4 \mathrm{DAI}$ and the greatest activity was detected in tomato leaves treated with a Trichoderma sp. + BR. SOD activity was 1.4-fold, 1.0-fold, and 2.0-fold higher than the SOD activities in the control for Trichoderma sp. alone, BR alone, and Trichoderma sp. + BR, respectively, at 4 DAI (Fig. 5C).

PAL activity detected in tomato leaves peaked at 2 DAI after treatment with Trichoderma sp. alone or Trichoderma sp. + BR. In these two treatments, PAL activity was 3.6-fold and 5.2-fold higher than the activity in the control at $2 \mathrm{DAI}(P<0.05)$. The PAL activity in extracts of tomato leaves treated with BR alone was lower than that in leaves treated with the Trichoderma sp. + BR at 2 DAI (Fig. 5D).

\section{Discussion}

In this study, FCM from T. atroviride CCTCCSBW0199 inhibited growth of $B$. cinerea, indicating that metabolites produced by this strain were antagonistic to $B$. cinerea growth. An aspinolide (AspC) from T. arundinaceum (Ta37) has been shown to downregulate the $B$. cinerea virulence genes BcatrB, BMPl, and $B c p g l$ in the presence of the sesquiterpenoid harzianum $A$ or other unidentified secondary metabolites produced by $T$. arundinaceum (Malmierca et al. 2016).

Our study demonstrated that BR inhibits the growth of $B$. cinerea. BR promotes plant stem elongation and cell division and improves plant disease resistance, functioning as a defense signal for inducing expression of plant defense response-related genes ( $\mathrm{Li}$ and Chory 1999; Zurek et al. 1994). This present study reports a direct inhibitory effect of BR on B. cinerea which may have caused the pathogen to be

Table 3. Inhibitory effects of applied concentrations of brassinolide (BR) + Trichoderma atroviride CCTCCSBW0199 against Botrytis cinerea

\begin{tabular}{lcc}
\hline Treatment & $\begin{array}{c}\text { Pathogen colony } \\
\text { diameter }(\mathbf{c m})\end{array}$ & Percent inhibition $(\%)^{\mathbf{z}}$ \\
\hline $\begin{array}{l}\text { T. atroviride + BR at } \\
1 \mu \mathrm{g} / \mathrm{ml}\end{array}$ & $2.4 \pm 0$ & $70.3 \mathrm{~B}$ \\
$\begin{array}{l}\text { T. atroviride + BR at } \\
0.2 \mu \mathrm{g} / \mathrm{ml}\end{array}$ & $2.0 \pm 0$ & $74.6 \mathrm{~A}$ \\
$\begin{array}{l}\text { T. atroviride + BR at } \\
\quad .1 \mu \mathrm{g} / \mathrm{ml}\end{array}$ & $2.4 \pm 0.2$ & $69.9 \mathrm{~B}$ \\
Control & $2.6 \pm 0$ & $67.0 \mathrm{C}$ \\
\hline
\end{tabular}

${ }^{\mathrm{z}}$ Different uppercase letters in the same column indicate significant differences among treatments $(P<0.05)$.

Table 4. Disease index and percent control of applied concentrations of Trichoderma atroviride CCTCCSBW0199 fermented cultures containing chlamydospores and metabolites (FCCM) + brassinolide (BR) solution at $0.2 \mu \mathrm{g} / \mathrm{ml}$ against gray mold on tomato leaves ${ }^{\mathrm{z}}$

\begin{tabular}{|c|c|c|}
\hline Treatment & $\begin{array}{c}\text { Disease } \\
\text { index }\end{array}$ & $\begin{array}{c}\text { Percent } \\
\text { control }(\%)\end{array}$ \\
\hline T. atroviride FCCM at $10^{6}$ spores $/ \mathrm{ml}$ & $8.8 \mathrm{~A}$ & $71.3 \mathrm{~A}$ \\
\hline T. atroviride $\mathrm{FCCM}$ at $10^{7}$ spores $/ \mathrm{ml}$ & $11.3 \mathrm{C}$ & $65.4 \mathrm{~B}$ \\
\hline T. atroviride $\mathrm{FCCM}$ at $10^{8}$ spores $/ \mathrm{ml}$ & $12.2 \mathrm{~B}$ & $61.1 \mathrm{D}$ \\
\hline T. atroviride $\mathrm{FCCM}$ at $10^{9}$ spores $/ \mathrm{ml}$ & $12.0 \mathrm{C}$ & $63.3 \mathrm{C}$ \\
\hline $\begin{array}{l}\text { T. atroviride } \mathrm{FCCM} \text { at } 10^{6} \text { spores } / \mathrm{ml}+\mathrm{BR} \text { at } \\
0.2 \mu \mathrm{g} / \mathrm{ml}\end{array}$ & $12.9 \mathrm{~B}$ & $62.1 \mathrm{C}$ \\
\hline $\begin{array}{l}\text { T. atroviride } \mathrm{FCCM} \text { at } 10^{7} \text { spores } / \mathrm{ml}+\mathrm{BR} \text { at } \\
0.2 \mu \mathrm{g} / \mathrm{ml}\end{array}$ & $9.6 \mathrm{~A}$ & $69.2 \mathrm{~B}$ \\
\hline $\begin{array}{l}\text { T. atroviride } \mathrm{FCCM} \text { at } 10^{8} \text { spores } / \mathrm{ml}+\mathrm{BR} \text { at } \\
0.2 \mu \mathrm{g} / \mathrm{ml}\end{array}$ & $8.2 \mathrm{~A}$ & $74.8 \mathrm{~A}$ \\
\hline $\begin{array}{l}\text { T. atroviride } \mathrm{FCCM} \text { at } 10^{9} \text { spores } / \mathrm{ml}+\mathrm{BR} \text { at } \\
0.2 \mu \mathrm{g} / \mathrm{ml}\end{array}$ & $10.4 \mathrm{~B}$ & $69.1 \mathrm{~B}$ \\
\hline Control & $32.7 \mathrm{D}$ & $\ldots$ \\
\hline
\end{tabular}

${ }^{\mathrm{z}}$ Different uppercase letters in the same column indicate significant differences among treatments at the 0.05 level. 
more vulnerable to Trichoderma parasitism. This finding was supported by the induction of enlarged empty vacuoles in $B$. cinerea mycelia by BR (Fig. 2). Deformed vacuoles might lead to the loss of a variety of functions such as those related to the accumulation of amino acids and inorganic polyphosphates, $\mathrm{pH}$ balance, an optimal cellular ion concentration, osmotic pressure regulation, and removal of cellular toxic substances (Cramer et al. 1980; Shubin et al. 2016).

The growth and sporulation of Trichoderma spp. was not affected by different concentrations of BR compared with the control. In contrast, Trichoderma mycelia and spores grew better under some concentrations of BR solution than in the control. The influence of BR on the growth and sporulation of Trichoderma spp. was dependent on the BR concentration applied. For example, the greatest degree of Trichoderma growth and sporulation was promoted at BR concentrations of 0.2 and $1 \mu \mathrm{g} / \mathrm{ml}$, respectively. Under other conditions, the effects of BR on the growth and sporulation of Trichoderma spp. were not significant. The reason for this difference is unclear but it may be related to the fact that Trichoderma fungi have different sensitivities to BR stress (Osiewacz 2002).

BR had different effects on the growth of B. cinerea and Trichoderma spp. Study revealed that a BR solution resulted in $20.0 \%$ inhibition of Bipolaris maydis (Ni et al. 2017). Research indicated that fungicide oxime ethers acyl hydrazone B1 inhibited the growth of Rhizoctonia solani by $80 \%$ but did not inhibit growth of Botrytis cinerea (Jiao et al. 2011). Thus, it is possible that BR could be likened to a fungicide; its inhibition effect is genus specific and different fungi have different sensitivities or specific responses to BR stress.

The higher inhibitory rates of the Trichoderma sp. + BR indicated that they had a synergistic inhibitory effect on the pathogen, although the synergistic action depended on the concentration of BR. Greenhouse evaluations supported the synergistic effect of a Trichoderma sp. + BR except at the lowest concentration of FCCM. When FCCM was applied alone, the lowest concentration resulted in the highest percent control of gray mold. A possible reason for this observation is that control of tomato gray mold was unstable with FCCM alone and the synergistic effect depended on the concentrations of
Trichoderma spp. and BR used. Specifically, Trichoderma FCCM at $1 \times 10^{8}$ spores $/ \mathrm{ml}+$ BR solution at $0.2 \mu \mathrm{g} / \mathrm{ml}$ inhibited $74.8 \%$ of pathogen growth, suggesting that this was the best combined formulation under our conditions. However, the mechanism of synergistic effect remains unclear.

A sequential application of $T$. atroviride FCCM at $1 \times 10^{8}$ spores/ $\mathrm{ml}+\mathrm{BR}$ at $0.2 \mu \mathrm{g} / \mathrm{ml}(24 \mathrm{~h}$ later $)$ and $T$. atroviride $\mathrm{FCCM}$ at $1 \times 10^{8}$ spores $/ \mathrm{ml}+\mathrm{BR}$ at $0.2 \mu \mathrm{g} / \mathrm{ml}$ showed no significant differences on the percent control. Hence, for convenience, simultaneous application of T. atroviride FCCM at $1 \times 10^{8}$ spores $/ \mathrm{ml}+\mathrm{BR}$ at $0.2 \mu \mathrm{g} / \mathrm{ml}$ was used in subsequent experiments.

Table 5. Disease index and percent control of application sequences of Trichoderma atroviride CCTCCSBW0199 fermented cultures containing chlamydospores and metabolites $(\mathrm{FCCM})+$ brassinolide $(\mathrm{BR})$ at $0.2 \mu \mathrm{g} / \mathrm{ml}$ solution against gray mold on tomato leaves

\begin{tabular}{|c|c|c|}
\hline Treatment $^{\mathrm{y}}$ & $\begin{array}{c}\text { Disease } \\
\text { index }\end{array}$ & $\begin{array}{c}\text { Percent } \\
\text { control }(\%)^{\mathrm{z}}\end{array}$ \\
\hline $\begin{array}{l}\text { T. atroviride } \mathrm{FCCM} \text { at } 10^{8} \text { spores } / \mathrm{ml}+\mathrm{BR} \text { at } \\
0.2 \mu \mathrm{g} / \mathrm{ml}(24 \mathrm{~h} \text { later) }\end{array}$ & 11.1 & $74.6 \mathrm{~A}$ \\
\hline $\begin{array}{l}\text { BR at } 0.2 \mu \mathrm{g} / \mathrm{ml}+T \text {. atroviride FCCM at } \\
10^{8} \text { spores } / \mathrm{ml}(24 \mathrm{~h} \text { later })\end{array}$ & 13.3 & $69.3 \mathrm{~B}$ \\
\hline $\begin{array}{l}\text { T. atroviride } \mathrm{FCCM} \text { at } 10^{8} \text { spores } / \mathrm{ml}+\mathrm{BR} \text { at } \\
0.2 \mu \mathrm{g} / \mathrm{ml} \text { (at the same time) }\end{array}$ & 11.1 & $74.4 \mathrm{~A}$ \\
\hline Control & 43.3 & ... \\
\hline T. atroviride FCCM alone at $10^{8}$ spores $/ \mathrm{ml}$ & 23.3 & $46.2 \mathrm{C}$ \\
\hline $\mathrm{BR}$ alone at $0.2 \mu \mathrm{g} / \mathrm{ml}$ & 26.7 & $38.3 \mathrm{C}$ \\
\hline
\end{tabular}

y $T$. atroviride $\mathrm{FCCM}$ at $10^{8}$ spores $/ \mathrm{ml}+\mathrm{BR}$ at $0.2 \mu \mathrm{g} / \mathrm{ml}(24 \mathrm{~h}$ later) means using BR at $0.2 \mu \mathrm{g} / \mathrm{ml} 24 \mathrm{~h}$ later than T. atroviride FCCM at $10^{8}$ spores $/ \mathrm{ml}$; BR at $0.2 \mu \mathrm{g} / \mathrm{ml}+T$. atroviride FCCM at $10^{8}$ spores $/ \mathrm{ml}$ (24 h later) means using T. atroviride FCCM at $10^{8}$ spores $/ \mathrm{ml} 24$ h later than BR at $0.2 \mu \mathrm{g} / \mathrm{ml}$; and T. atroviride FCCM at $10^{8}$ spores $/ \mathrm{ml}+\mathrm{BR}$ at $0.2 \mu \mathrm{g} / \mathrm{ml}$ (at the same time) means using them at the same time.

${ }^{\mathrm{z}}$ Different uppercase letters in the same column indicate significant differences among treatments at the 0.05 level.
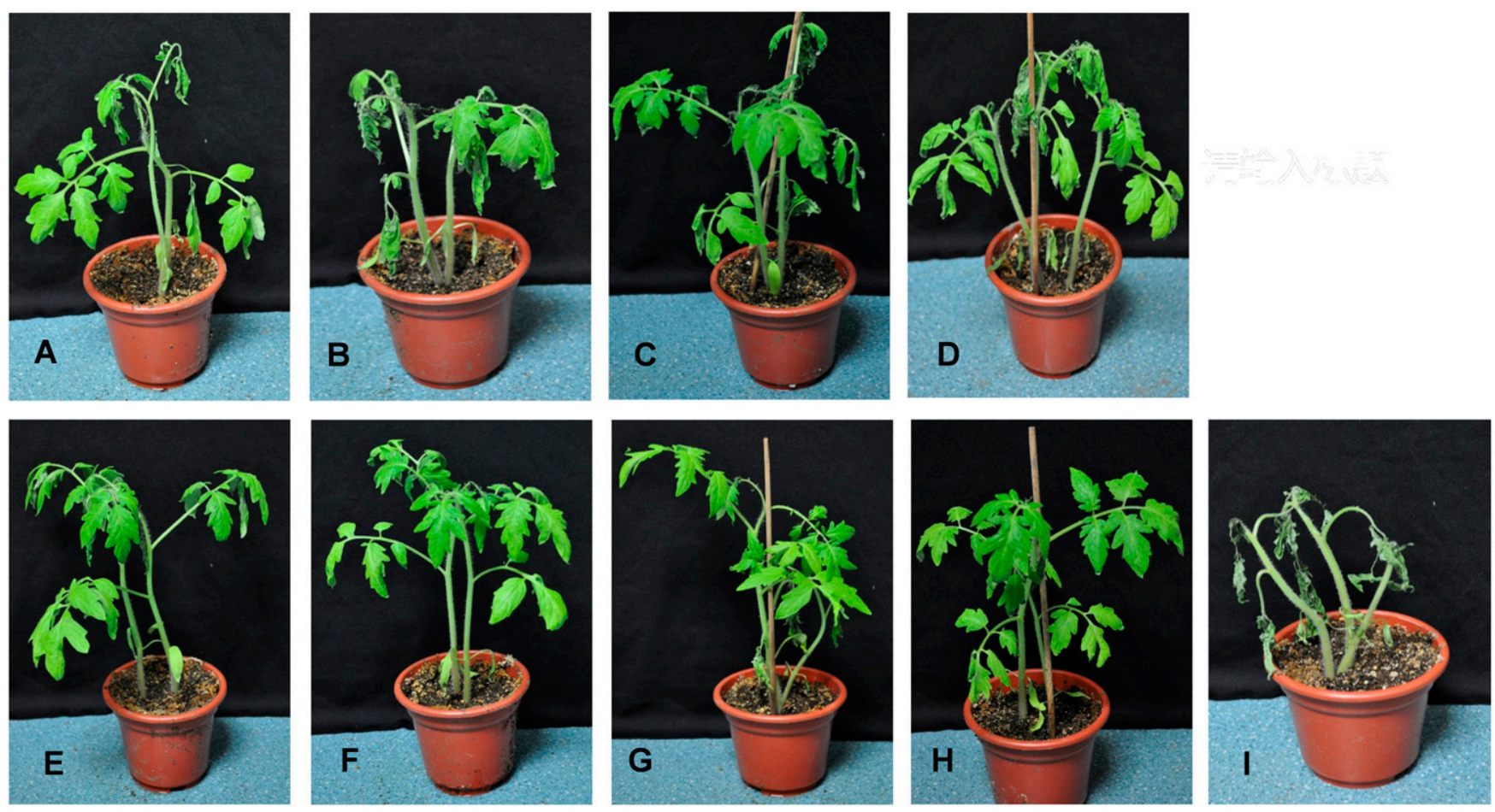

Fig. 4. Control efficiency of applied concentrations of Trichoderma atroviride CCTCCSBW0199 fermented cultures containing chlamydospores and metabolites (FCCM) + brassinolide (BR) solution at $0.2 \mu \mathrm{g} / \mathrm{ml}$ against gray mold on tomato leaves 5 days after inoculation with Botrytis cinerea. A, T. atroviride FCCM at $10^{6}$ spores/ml; B, T. atroviride FCCM at $10^{7}$ spores $/ \mathrm{ml} ;$ C, T. atroviride FCCM at $10^{8}$ spores $/ \mathrm{ml} ;$ D, T. atroviride FCCM at $10^{9}$ spores $/ \mathrm{ml} ;$ E, T. atroviride FCCM at $10^{6}$ spores $/ \mathrm{ml}+$ BR at $0.2 \mu \mathrm{g} / \mathrm{ml} ; \mathrm{F}, T$. atroviride FCCM at $10^{7} \mathrm{spores} / \mathrm{ml}+\mathrm{BR}$ at $0.2 \mu \mathrm{g} / \mathrm{ml} ; \mathbf{G}, T$. atroviride FCCM at $10^{8} \mathrm{spores} / \mathrm{ml}+\mathrm{BR}$ at $0.2 \mu \mathrm{g} / \mathrm{ml} ; \mathrm{H}, \mathrm{T}$. atroviride FCCM at $10^{9} \mathrm{spores} / \mathrm{ml}+$ BR at $0.2 \mu \mathrm{g} / \mathrm{ml}$; and I, control (sterile water). 
A
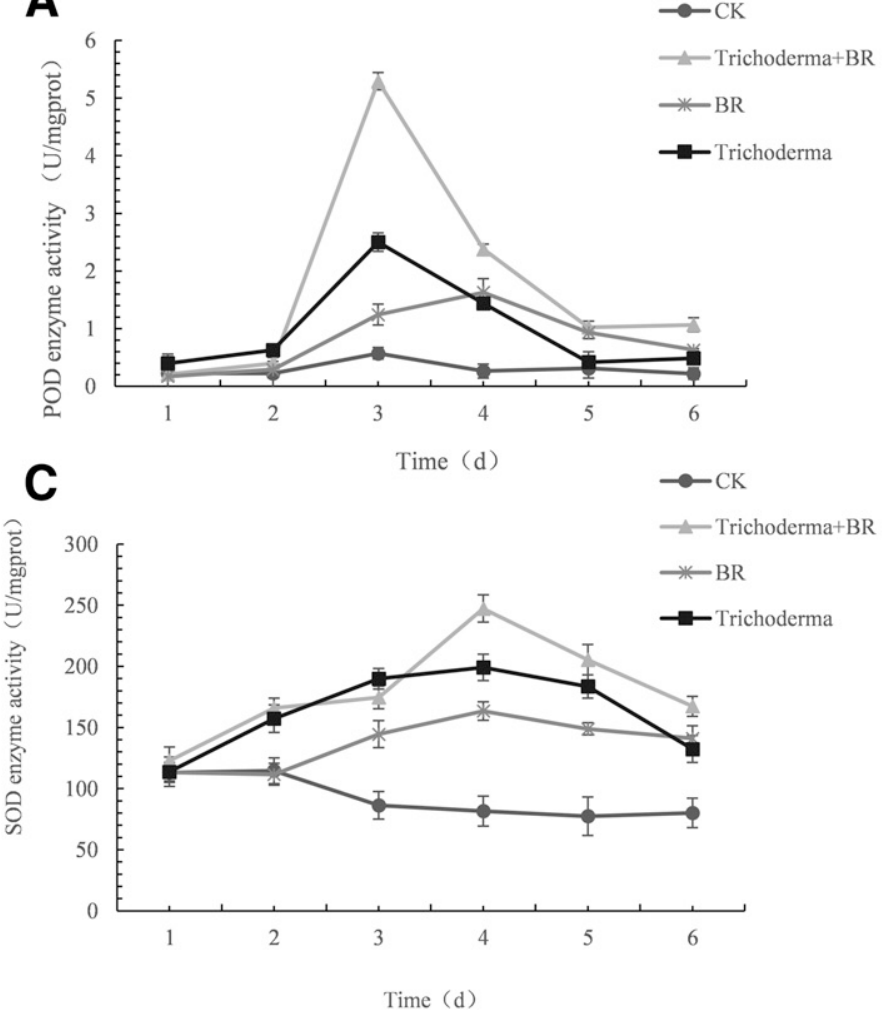

B

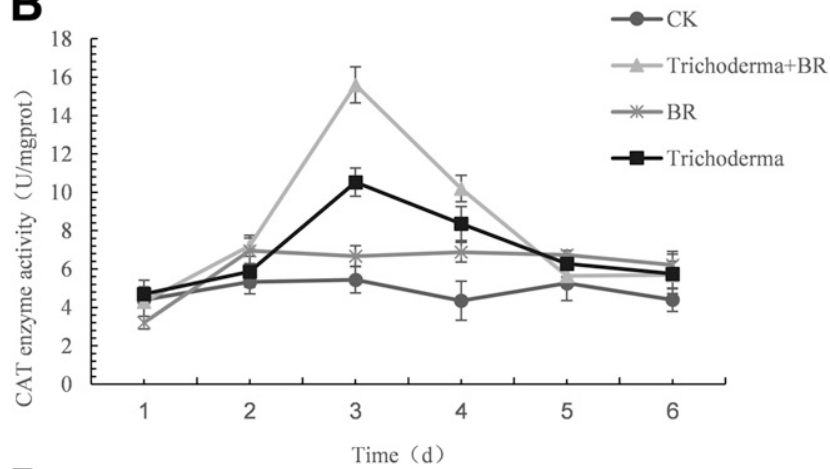

D

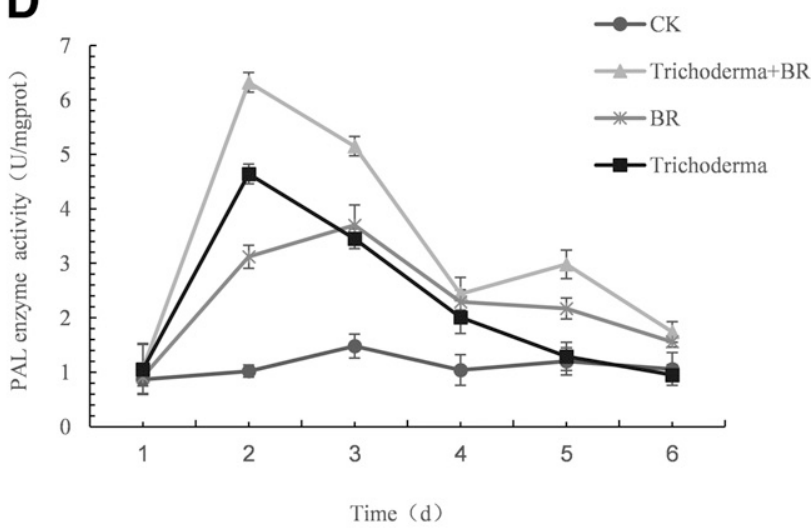

Fig. 5. Effects of Trichoderma atroviride CCTCCSBW0199 fermented cultures containing chlamydospores and metabolites (FCCM) + brassinolide (BR) at $0.2 \mu \mathrm{g} / \mathrm{ml}$ on defense enzymes associated with resistance against Botrytis cinerea on tomato leaves. A, Peroxidase (POD) enzyme activity; B, catalase (CAT) enzyme activity; C, superoxide dismutase (SOD) enzyme activity; and D, phenylalanine ammonia-lyase (PAL) enzyme activity. Time points are days after treatment with $T$. atroviride, BR, T. atroviride + BR, or control (CK; sterile water).

The Trichoderma sp. + BR stimulated higher activities of the antioxidant enzymes SOD, POD, CAT, and PAL in tomato leaves than treatment with either Trichoderma spp. or BR alone, suggesting that the combination of a Trichoderma sp. + BR stimulates the expression of antioxidant-enzyme-related genes. Z.-r. Zhang et al. (2017) showed that the activity of PAL and POD enzymes was consistent with the change of gene expression. Meanwhile, this phenomenon might explain the mechanism of the synergistic effect. SOD is known to scavenge free radicals accumulated in infected plants, thereby preventing damage to plant cell membranes and delaying senescence (Giannopolitis and Ries 1977). POD is a key enzyme in lignin synthesis that can strengthen the plant cell wall structure and provide protection against pathogenic infection (Hegedüs et al. 2001). CAT plays a key role in the clearance of hydrogen peroxide in plants (Asghari and Aghdam 2010) and as a receptor for salicylic acid to enhance plant resistance to diseases ( $\mathrm{Li}$ and $\mathrm{Li} 2007$ ). PAL activity is closely associated with levels of plant phytoalexins, lignins, and phenolic compounds (Aghdam et al. 2012). We suggest that the increased activity we detected in these antioxidant enzymes with the use of a Trichoderma sp. + BR led to better host plant resistance to gray mold infection in tomato.

To the best of our knowledge, this study is the first to report the combined application of T. atroviride CCTCCSBW0199 and the plant growth regulator $\mathrm{BR}$ to synergistically prevent tomato gray mold. The synergistic action of T. atroviride FCCM at $1 \times 10^{8}$ spores $/ \mathrm{ml}+\mathrm{BR}$ at $0.2 \mu \mathrm{g} / \mathrm{ml}$ in the control of tomato gray mold caused by $B$. cinerea was confirmed. The genus Trichoderma was previously demonstrated to have a strong capacity to induce resistance in tomato (Martínez-Medina et al. 2013), and BR significantly promotes tomato growth and resistance to stress (Vardhini et al. 2008, 2010). The application of a Trichoderma sp. + BR enhanced the growth and sporulation of Trichoderma spp. at specific concentrations, inhibited growth of $B$. cinerea, and increased resistance to gray mold in tomato. Therefore, this combination may lead to a more stable control efficiency against $B$. cinerea infection in tomato.

\section{Literature Cited}

Aghdam, M. S., Asghari, M., Farmani, B., Mohayeji, M., and Moradbeygi, H. 2012. Impact of postharvest brassinosteroids treatment on PAL activity in tomato fruit in response to chilling stress. Sci. Hortic. (Amsterdam) 144:116-120.

Ali, S. S., Gunupuru, L. R., Kumar, G. S., Khan, M., Scofield, S., Nicholson, P., and Doohan, F. M. 2014. Plant disease resistance is augmented in uzu barley lines modified in the brassinosteroid receptor BRI1. BMC Plant Biol. 14:227.

Alici, E. H., and Arabaci, G. 2016. Determination of SOD, POD, PPO and cat enzyme activities in Rumex obtusifolius L. Annu. Res. Rev. Biol. 11:1-7.

Asghari, M., and Aghdam, M. S. 2010. Impact of salicylic acid on post-harvest physiology of horticultural crops. Trends Food Sci. Technol. 21:502-509.

Buckley, P. M., Sjaholm, V. E., and Sommer, N. 1966. Electron microscopy of Botrytis cinerea conidia. J. Bacteriol. 91:2037-2044.

Chen, H.-H., Shen, Z.-Y., and Li, P. 1982. Adaptability of crop plants to high temperatures stress 1. Crop Sci. 22:719-725.

Cheng, C.-H., Yang, C.-A., and Peng, K.-C. 2012. Antagonism of Trichoderma harzianum ETS 323 on Botrytis cinerea mycelium in culture conditions. Phytopathology 102:1054-1063.

Clouse, S. D., and Sasse, J. M. 1998. Brassinosteroids: Essential regulators of plant growth and development. Annu. Rev. Plant Biol. 49:427-451.

Cramer, C. L., Vaughn, L. E., and Davis, R. H. 1980. Basic amino acids and inorganic polyphosphates in Neurospora crassa: Independent regulation of vacuolar pools. J. Bacteriol. 142:945-952.

Damghan, I. 2009. Exogenous application of brassinosteroid alleviates droughtinduced oxidative stress in Lycopersicon esculentum 1. Gen. Appl. Plant Physiol. 35:22-34.

Elad, Y., and Shtienberg, D. 1995. Botrytis cinerea in greenhouse vegetables: Chemical, cultural, physiological and biological controls and their integration. Integr. Pest Manage. Rev. 1:15-29.

Fernández, E., Segarra, G., and Trillas, M. I. 2014. Physiological effects of the induction of resistance by compost or Trichoderma asperellum strain T34 against Botrytis cinerea in tomato. Biol. Control 78:77-85.

Giannopolitis, C. N., and Ries, S. K. 1977. Superoxide dismutases: I. Occurrence in higher plants. Plant Physiol. 59:309-314.

Giese, E. C., Covizzi, L. G., Dekker, R. F., Monteiro, N. K., Da Silva, M. L. C., and Barbosa, A. M. 2006. Enzymatic hydrolysis of botryosphaeran and laminarin by $\beta$-1,3-glucanases produced by Botryosphaeria rhodina and Trichoderma harzianum Rifai. Process Biochem. 41:1265-1271.

Hannusch, D., and Boland, G. 1996. Interactions of air temperature, relative humidity and biological control agents on grey mold of bean. Eur. J. Plant Pathol. 102:133-142. 
Harel, Y. M., Mehari, Z. H., Rav-David, D., and Elad, Y. 2014. Systemic resistance to gray mold induced in tomato by benzothiadiazole and Trichoderma harzianum T39. Phytopathology 104:150-157.

Harman, G. E. 2006. Overview of mechanisms and uses of Trichoderma spp. Phytopathology 96:190-194.

Hegedüs, A., Erdei, S., and Horváth, G. 2001. Comparative studies of $\mathrm{H}_{2} \mathrm{O}_{2}$ detoxifying enzymes in green and greening barley seedlings under cadmium stress. Plant Sci. 160:1085-1093.

Ho, W. H., To, P. C., and Hyde, K. D. 2003. Induction of antibiotic production of freshwater fungi using mix-culture fermentation. Fungal Divers. 12:45-51.

Jiao, Y., Wenjing, X., and Aixi, H. 2011. Synthesis, crystal structure and fungicidal activity of (Z)-3, 3-dimethyl-1-(1H-1, 2, 4-triazol-1-yl) butan-2-one O-2chlorobenzyl oxime nitrate. Chin. J. Struct. Chem. 30:1265-1268.

Jing, J., Yuhua, Z., Xiao-Qian, Y., Rongping, J., Dong-Mei, G., and Xi, C. 2012. The influence of microwave radiation from cellular phone on fetal rat brain. Electromagn. Biol. Med. 31:57-66.

Kamuro, Y., and Inada, K. 1991. The effect of brassinolide on the light-induced growth inhibition in mung bean epicotyl. Plant Growth Regul. 10:37-43.

Lei, Z. 1998. A preliminary study on antagonistic mechanism of Trichoderma viride against Botrytis cinerea. Plant Protection 24:36-37.

Li, J., and Chory, J. 1999. Brassinosteroid actions in plants. J. Exp. Bot. 50: $275-282$.

Li, R., and Li, X. 2007. Effects of salicylic acid, abscisic acid and hydrogen peroxide on the photosynthesis and antioxidase activities of wheat under cadmium stress. Shengtaixue Zazhi 26:2096-2099.

Li, R.-X., Cai, F., Pang, G., Shen, Q.-R., Li, R., and Chen, W. 2015. Solubilisation of phosphate and micronutrients by Trichoderma harzianum and its relationship with the promotion of tomato plant growth. PLoS One 10:e0130081.

Liu, S., Che, Z., and Chen, G. 2016. Multiple-fungicide resistance to carbendazim, diethofencarb, procymidone, and pyrimethanil in field isolates of Botrytis cinerea from tomato in Henan Province, China. Crop Prot. 84:56-61.

Malmierca, M. G., Izquierdo-Bueno, I., McCormick, S. P., Cardoza, R. E., Alexander, N. J., Barua, J., Lindo, L., Casquero, P. A., Collado, I. G., Monte, E., and Gutierrez, S. 2016. Trichothecenes and aspinolides produced by Trichoderma arundinaceum regulate expression of Botrytis cinerea genes involved in virulence and growth. Environ. Microbiol. 18:3991-4004.

Mandava, N. B. 1988. Plant growth-promoting brassinosteroids. Annu. Rev. Plant Physiol. Plant Mol. Biol. 39:23-52.

Martínez-Medina, A., Fernández, I., Sánchez-Guzmán, M. J., Jung, S. C., Pascual, J. A., and Pozo, M. J. 2013. Deciphering the hormonal signalling network behind the systemic resistance induced by Trichoderma harzianum in tomato. Front. Plant Sci. 4:206.

Masih, E. I., and Paul, B. 2002. Secretion of $\beta$-1, 3-glucanases by the yeast Pichia membranifaciens and its possible role in the biocontrol of Botrytis cinerea causing grey mold disease of the grapevine. Curr. Microbiol. 44:391-395.

Ni, X., Wang, M., Guan, S., and Chen, J. 2017. Research of prevention and control of Bipolaris maydis with Brassinolide and chemical pesticides. J. Shanghai Jiaotong Univ. (Agric. Sci.) 35:31-36, 44.

Ning, X. 2013. Occurrence and control strategies of tomato gray mold in greenhouse. NongMinZhiFuZhiYou 24:60-60.

Nomura, T., Kushiro, T., Yokota, T., Kamiya, Y., Bishop, G. J., and Yamaguchi, S. 2005. The last reaction producing brassinolide is catalyzed by cytochrome P-450s, CYP85A3 in tomato and CYP85A2 in Arabidopsis. J. Biol. Chem. 280:17873-17879.

Osiewacz, H. D., ed. 2002. Molecular Biology of Fungal Development. CRC Press, Boca Raton, FL, U.S.A.
Sauer, D., and Burroughs, R. 1986. Disinfection of seed surfaces with sodium hypochlorite. Phytopathology 76:745-749.

Shubin, A. V., Demidyuk, I. V., Komissarov, A. A., Rafieva, L. M., and Kostrov, S. V. 2016. Cytoplasmic vacuolization in cell death and survival. Oncotarget 7 : 55863-55889.

Sun, H.-Y., Wang, H.-C., Chen, Y., Li, H.-X., Chen, C.-J., and Zhou, M.-G. 2010. Multiple resistance of Botrytis cinerea from vegetable crops to carbendazim, diethofencarb, procymidone, and pyrimethanil in China. Plant Dis. 94:551-556.

Te'o, V. S. J., Bergquist, P. L., and Nevalainen, K. M. H. 2002. Biolistic transformation of Trichoderma reesei using the Bio-Rad seven barrels Hepta Adaptor system. J. Microbiol. Methods 51:393-399.

Vardhini, B. V., Anuradha, S., Sujatha, E., and Rao, S. S. R. 2010. Role of brassinosteroids in alleviating various abiotic and biotic stresses-A review. Plant Stress 4:56-61.

Vardhini, B. V., Rao, S., and Rao, K. 2008. Effect of brassinolide on growth, yield, metabolite content and enzyme activities of tomato (Lycopersicon esculentum) Mill. Pages 133-139 in: Recent Advances in Plant Biotechnology and its Applications. A. Kumar and S. K. Sopory, eds. IK International Publishing House Ltd., New Delhi, India.

Wang, H., Shi, Y., Wang, D., Yao, Z., Wang, Y., Liu, J., Zhang, S., and Wang, A. 2018. A Biocontrol strain of Bacillus subtilis WXCDD105 used to control tomato Botrytis cinerea and Cladosporium fulvum Cooke and promote the growth of seedlings. Int. J. Mol. Sci. 19:1371.

Wang, R., Zheng, X., Liu, Y., Wang, Y., Zhao, Q., Zhang, Y., and Sun, Z. 2017. The study on the control effect of composite application of BR on Meloidogyne spp. in tomato. J. Henan Agric. Univ. 51:29-35.

Wright, R. 2000. Transmission electron microscopy of yeast. Microsc. Res. Tech. 51:496-510.

Xia, X. J., Zhou, Y. H., Ding, J., Shi, K., Asami, T., Chen, Z., and Yu, J. Q. 2011 Induction of systemic stress tolerance by brassinosteroid in Cucumis sativus. New Phytol. 191:706-720.

Yau, Y.-Y., Wang, Y., Thomson, J. G., and Ow, D. W. 2011. Method for Bxb1mediated site-specific integration in planta. Pages 147-166 in: Plan Chromosome Engineering. J. Birchler, ed. Methods in Molecular Biology (Methods and Protocols), vol. 701. Humana Press, Totowa, NJ, U.S.A.

Yu, C., Gao, J., Dou, K., Wang, M., Sun, J., Lu, Z., Li, Y., and Chen, J. 2016. Induction of Curvularia leaf spot systematic resistance in maize by Trichoderma harzianum gene Hydl. Page 1 in: China Plant Protection Society 2016 Academic Annual Meeting, Cheng Du, China.

Yuan, D. P., Zhang, C., Wang, Z. Y., Zhu, X. F., and Xuan, Y. H. 2018. RAVL1 activates brassinosteroids and ethylene signaling to modulate response to sheath blight disease in rice. Phytopathology 108:1104-1113.

Zhang, J., Chen, J., Liu, Z., Guan, S., Li, J., Zhang, C., Wang, W., Jiang, X., and Zhang, J. 2017. Evaluation of the combined use of Trichoderma atroviride metabolite and Brassinolide in the promotion of vegetable growth and control of Botrytis cinerea. J. Shanghai Jiaotong Univ. (Agric. Sci.) 35:1-7.

Zhang, Z.-r., Zhang, R.-j., Zhao, Y.-t., and Zhu, X. 2017. Effects of salicylic acid and chitosan oligosaccharide on resistance to black rot and PAL and POD activity and their gene expression in postharvest apricot fruits. J. Xinjiang Agric. Univ. 40:179-184.

Zhao, Y., Miao, Z., and Li, Y. 2014. Research progress on controlling against tomato gray mold. China Plant Prot. 7:21-29.

Zurek, D. M., Rayle, D. L., McMorris, T. C., and Clouse, S. D. 1994. Investigation of gene expression, growth kinetics, and wall extensibility during brassinosteroid-regulated stem elongation. Plant Physiol. 104:505-513. 